\title{
ミクロ，メソ多孔体内の気・液相内の拡散機構
}

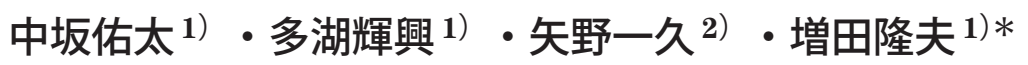 \\ 1）北海道大学 大学院工学研究科 有機プロセス工学専攻 $\overline{\mathrm{T}} 060-8628$ 北海道札幌市北区北 13 条西 8 丁目 \\ 2）株式会社豊田中央研究所 フロンティア研究部門％ 480-1192 愛知県愛知郡長久手町
}

\section{Diffusion Mechanisms within Microporous and Mesoporous Materials in Gas and Liquid Phases}

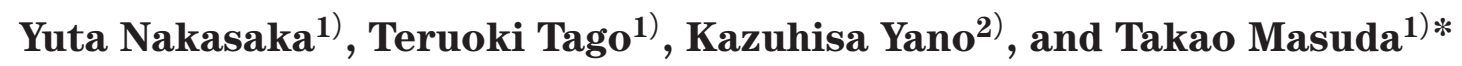 \\ 1) Division of Chemical Process Engineering, Graduate School of Engineering, Hokkaido University \\ N13_W8, Kita-ku, Sapporo 060-8628, Japan \\ 2) Frontier Research division, Toyota Central R\&D Labs., Inc. \\ Nagakute, Aichi 480-1192, Japan
}

The diffusivities of hydrocarbons within zeolite in gas phase have been measured widely. On the other hand, there have been few reports concerning measurements of the diffusivities of molecules within catalysts in the liquid phase as compared with those in the gas phase, because it is difficult to measure directly and continuously the change in the diffusate concentrations with time due to adsorption and diffusion into the catalysts in the liquid phase. In our recent research, we succeeded in developing a new method for measuring diffusivities within solid catalyst in liquid phase using Raman spectroscopy. Constant volumetric method was employed in this measurement, and diffusion mechanisms of hydrocarbons within solid catalyst were investigated by measuring separately intracrystalline diffusivity and partition factor. Intracrystalline diffusivity directly represents the mobility of molecules within pores. And the partition factor is the ratio of the diffusate concentration in solid catalyst to that in bulk phase, and means the concentration effect. Effective diffusivity is obtained by multiplying the intracrystalline diffusivity by the partition factor. In this manuscript, we review intracrystalline and effective diffusivities of hydrocarbons within porous solid catalyst in gas and liquid phases by introducing our recent research.

Key words : diffusion $/$ diffusivity $/$ gas and liquid phases $/$ zeolites $/$ mesoporous materials

\section{1.はじめに}

近年, 石油化学工業の分野を中心に，様々な固体 触媒が工業触媒として幅広く取り扱われている。固 体触媒反応では, まず反応物質が反応流体から触媒 細孔内を拡散し，細孔表面の活性点上で反応する。 そして，生成物が細孔内を触媒外表面に向かって拡

* Corresponding Author Tel : 011-706-6550 Fax : 011-706-6552

E-mail : takao@eng.hokudai.ac.jp
散した後, 反応流体に移動することで初めて触媒粒 子として反応活性が観測される，つまり，観測され る反応速度の上限值は拡散速度であり, 触媒活性点 上の反応速度と拡散速度の相対的な比によって触媒 の反応特性が大きく変化する．この影響が顕著に現 れる代表的な触媒としてゼオライト触媒がある。ゼ オライト触媒の細孔径は簡単な分子の大きさに匹敵 する為, 混合物を分子の大きさの違いで分離する分 子篩能や, 混合物中の目的物質のみを選択的に反応 させるといった特異な選択性（形状選択性）が現れ る. 特にゼオライト触媒を用いた反応では, 分子は 
Table 1 Experimental method for measuring diffusivity

\begin{tabular}{lll}
\hline \multicolumn{1}{c}{ Technique } & \multicolumn{1}{c}{ Viewpoint } & Ref. \\
\hline Pulse field gradient NMR (PFG NMR) & microscopic & 14 \\
Quasi-elastic neutron scattering (QENS) & microscopic & 15 \\
Gravimetric method & macroscopic (transient) & 16 \\
Constant volume method & macroscopic (transient) & 17 \\
Frequency response (FR) & macroscopic (transient) & 18 \\
Zero-length column technique (ZLC) & macroscopic (transient) & 19 \\
Chromatographic method & macroscopic (steady state) & 20 \\
Wicke-Kallenbach & macroscopic (steady state) & 21 \\
Effectiveness factor & & 22 \\
\hline
\end{tabular}

その動きを細孔壁, 細孔表面の吸着点そして共存分 子に制限されながら反応する。また，ゼオライトの 特性を利用したゼオライト膜による反応 ${ }^{1}$, 膜分離 2,3 についても盛んに研究されている. そのため, ゼ才 ライト触媒細孔内での分子の移動現象 (拡散挙動) を解明することは不可欠である。これまで，気相系 での拡散係数に関する報告は Zikanova ら ${ }^{4)}$ やShen ら 5) をはじめ多数なされている ${ }^{6 \sim 8)}$ 。しかし, 液相 系においてはFT（Fischer-Tropshe）反応を始めとし て実用化されているプロセスが多いにも関わらず報 告例はわずかである. Choudharyらは, volumetric sorption methodを用いて H-ZSM-5 内の hydrocarbon の単成分液相拡散係数を $274 \sim 338 \mathrm{~K}$ の温度領域で測 定した結果を報告している9,10)。また, Takahashi ら は，UV/VISを用いた Flow cell methodにより薄いシ リカプレート内の液相拡散係数を測定している ${ }^{11,12)}$. しかし, 未だゼオライト膜を用いた分離, 反応・分 離プロセス，そしてゼオライト粒子そのものを用い た液相反応の温度領域での拡散係数の測定值は十分 でない。さらに，液相拡散係数と細孔径との対応関 係については殆ど研究がなされていない状態である. そこで, 本稿では, 液相系のゼオライトを初めとし た固体触媒細孔内での拡散係数に関して, 最近の 我々の研究で得られた結果を中心に解説する.

\section{2. ゼオライトの拡散とその測定}

ゼオライト触媒の細孔内拡散係数には, ゼオライ トが接しているバルク中の分子の濃度基準 $\left[\mathrm{mol}\left(\mathrm{m}^{3}\right.\right.$ bulk phase $)^{-1}$ ]で定義される有効拡散係数（effective diffusivity, $D_{\text {eff }}$ ） と，ゼオライト結晶内の濃度基準 [mol ( $\mathrm{m}^{3}$-zeolite crystal $)^{-1}$ ]で定義される結晶内拡散 係数 (intracrystalline diffusivity, $D$ ) がある.Dはゼ オライト内の分子 $1 つ 1 つ の$ mobilityすなわち移動度 を表している．通常， $D_{\text {eff }}$ は Thiele modulusなど反応 速度解析に便宜上用いられるが，その值はそれほど

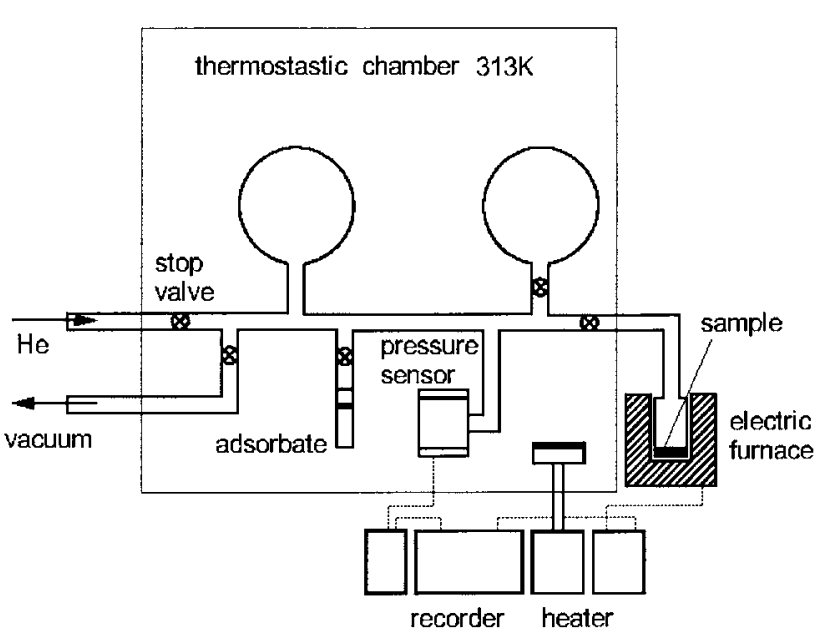

Fig. 1 Apparatus for measuring the intracrystalline diffusivity in the gas phase.

物理化学的意味を持たない. なぜなら,この $D_{\mathrm{eff}}$ の值 は, $D$ に分配係数 $H\left[\mathrm{~mol}\left(\mathrm{~m}^{3} \text {-zeolite crystal }\right)^{-1} / \mathrm{mol}\right.$ ( $\mathrm{m}^{3}$-bulk phase $)^{-1}$ ]を乗じることで求められるからで ある $\left(D_{\text {eff }}=H \times D\right)$. ここで定義される分配係数 $H$ [mol ( $\mathrm{m}^{3}$-adsorbent $\left.)^{-1} / \mathrm{mol}\left(\mathrm{m}^{3} \text {-bulk phase }\right)^{-1}\right]$ (こ こで, adsorbentは zeoliteを意味する) は, 吸着分子 の触媒中濃度と触媒に接するバルク中の吸着分子濃 度の比（無次元）で表され, ゼオライト細孔内の濃 縮効果を定量的に表す。

H-MFI型ゼオライト細孔内においては, パラフィ ンとオレフィンで 1000 倍程度結晶内拡散係数が異な る $\left(D_{\text {paraffin }}>D_{\text {olefin }}\right)$. しかしながら, 吸着能の違い から有効拡散係数はほぼ等しくなるということがわ かっている ${ }^{13)}$. このように, 見かけの拡散係数（有 効拡散係数）が等しくても細孔内部での物質移動現 象は異なる為, 拡散の評価を行う上では区別する必 要がある.

これまで, ゼオライトの拡散係数測定法について 多数の方法が提出されている（Table 1) 14 22). これ らは大きく 2 種類（微視的：microscopic, 巨視的： 


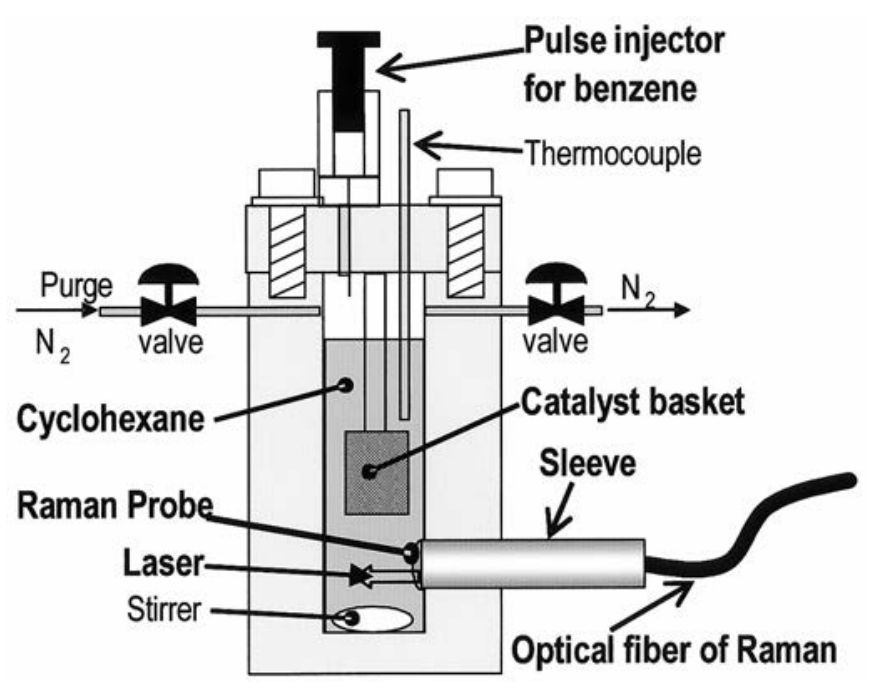

Fig. 2 Apparatus for measuring the intracrystalline diffusivity in the liquid phase.

macroscopic）に分けられる．微視的方法とは，NMR などを用いて直接拡散分子の平均移動距離を測定す ることで拡散係数を求める方法である．一方，巨視 的方法については，定常状態測定法（steady state） と非定常状態測定法（transient）に分けられる．定常 状態測定法のうち, Wiche-Kallenbach 法とは, 単結晶 膜中を定常的に透過する拡散物質の速度を直接測定 する方法である．また， effectiveness factor法とは， 異なる結晶径の触媒試料を用いて行った触媒反応の 見かけの反応速度から有効拡散係数を求める方法で ある。一方，非定常状態測定法（transient）とは，拡 散物質の吸着速度や脱着速度，あるいは吸脱着速度 の経時変化の実測值を拡散方程式の解でフィッティ ングすることで拡散係数を求める方法である.

一般に拡散係数は非定常測定法の重量法 (Gravimetric method) と定容法（Constant volume method）によって測定される，我々は，これまで定 容法を用い気相系について検討してきた。さらに， 気相系と同様に定容法を用い，液相系において新規 拡散係数測定方法の開発に成功している.

Fig. 1 は気相系で使用している定容法の装置図を示 す．ゼオライト試料を入れた試料管を含め，装置内 を真空に引いた後，試料管を除いた部分に拡散物質 の $100 \%$ 蒸気を導入する．試料管に拡散物質の蒸気を 導入して, 吸着に伴う全圧変化を圧力センサーによ り追跡し, その変化から吸着量の経時変化を求める.

Fig. 2 は液相系に打ける定容法の装置図を示す。白 金製の触媒籠に触媒を入れ，溶媒で満たした容器内 に吊るし，測定温度まで昇温する，昇温後，容器上 部より拡散物質をパルス状に導入し，触媒への吸着 に伴うバルク溶液中の拡散物質濃度の経時変化を,

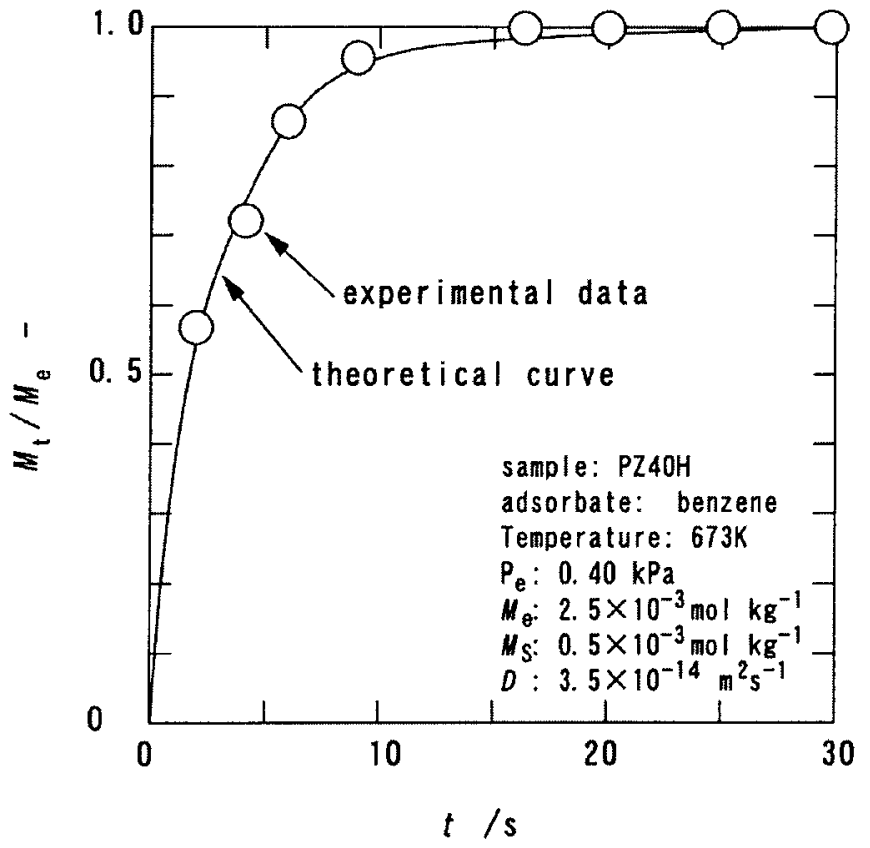

Fig. 3 Uptake curve of amount adsorbed onto MFI type zeolite in gas phase.

ラマン分光法を用いて追跡している.

ラマン分光法は, シングルモノクロメータタイプ の顕微レーザラマン分光装置の登場により飛躍的に 感度が向上し, 近年では広く利用されている. ラマ ン分光法の利点としては, 物質の状態に関係せずあ るがままの状態で測定が可能である点, ガラス越し の測定が可能である点, 水溶液の測定が容易である 点などが挙げられる。溶液濃度の測定には IRやUV などを用いることも可能である. しかし, IR光は水 の強くブロードな吸収ピークが他のピークと重なる 為に水溶液系の測定には不向きである. また, UVで は比較的薄いセルや薄膜試料が必要となる. ラマン 分光法はこれらの制約を受けない為, 比較的装置が 簡単なものとなり, in-situ, 高温領域での測定が可能 となる，さらには，様々な溶液系に対応が可能とな ると期待できる.

この様に，Dの測定方法は吸着過程および脱着過 程における拡散分子のゼオライト中の吸着量の経時 変化から理論式を用いて推算することになる. 以後 の本文およびFig. 4，5，7，9 と 10 に記述する $D_{\mathrm{ad}}$ は 吸着過程での吸着量の経時変化の実験結果を用いて 推算した $D$ の值を表す.

Fig. 1やFig. 2 の装置から得られる吸着過程の結晶 内拡散係数 $(D)$ は式 (1), (2) より求めることがで きる ${ }^{23)}$. 


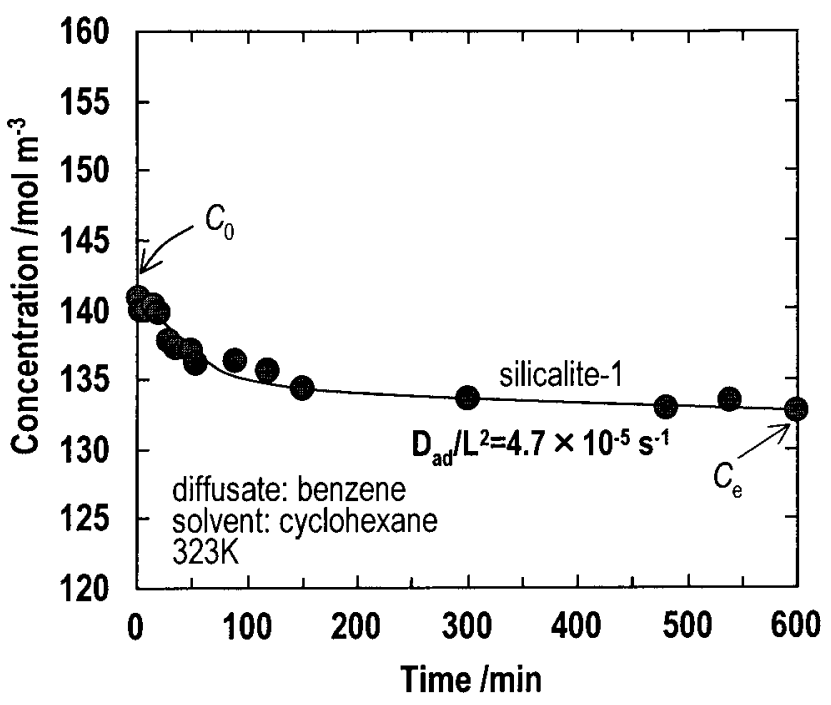

Fig. 4 The change in the benzene concentration with time. The symbols and the curve represent the experimental results and the numerical result calculated with theoretical equation, respectively.

[結晶が slab 形状のゼオライト，または一次元細孔 が拡散速度を支配する固体触媒：MFI型，モルデナ イト]

$$
\begin{aligned}
\frac{M_{t}}{M_{e}} & =\frac{C_{0}-C_{t}}{C_{0}-C_{e}} \\
& =1-\sum_{n=1}^{\infty} \frac{2 \alpha(1+\alpha)}{1+\alpha+\alpha^{2} q^{2}{ }_{n}} \exp \left(-\frac{D_{a d} q^{2} t}{L^{2}}\right)
\end{aligned}
$$

ここで, $M_{t}$ と $M_{\mathrm{e}}$ : 時間 $t$ と吸着平衡時それぞれの 吸着量, $C_{t}, C_{0}$ と $C_{e}$ : 時間 $t$, 吸着初期と平衡時それ ぞれのバルク中の拡散物質濃度, $2 L$ : 触媒結晶のサ イズ， $\alpha$ は吸着装置の体積と吸着骫（ゼオライト） の容積比を表すパラメータ： $\alpha=V /\left(a_{m} W H L\right)$, $q_{n}: \tan (q)=-\alpha q$ を満たす一連の解 $q$ の $n$ 番目の 正の解, $V$ : バルク相の体積, $W$ : 触媒量, $a_{m}$ : ゼ オライト単位質量あたりの外表面積である.

[結晶が sphere形状のゼオライト，または三次元細 孔が拡散速度を支配する固体触媒：Y型，A型ゼオラ イト]

$$
\begin{aligned}
\frac{M_{t}}{M_{e}} & =\frac{C_{0}-C_{t}}{C_{0}-C_{e}} \\
& =1-\sum_{n=1}^{\infty} \frac{6 \alpha(1+\alpha)}{9+9 \alpha+\alpha^{2} q_{n}^{2}} \exp \left[-D_{a d}\left(\frac{q_{n}}{R_{0}}\right)^{2} t\right]
\end{aligned}
$$

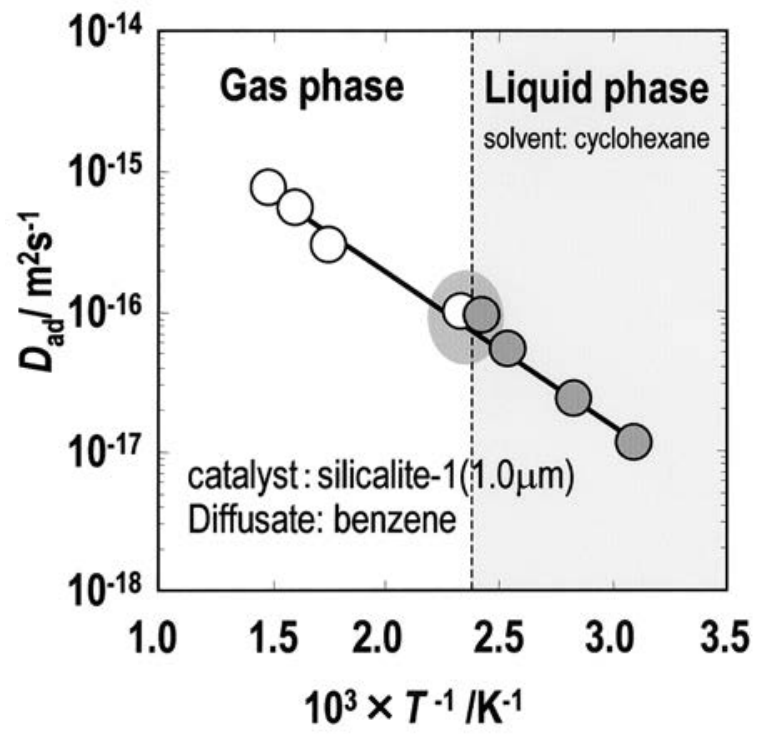

Fig. 5 Arrhenius plots of the intracrystalline diffusivity $\left(\mathrm{D}_{a d}\right)$ of benzene within silicalite- 1 in the gas and liquid phases.

ここで, $R_{0}$ : 触媒結晶の半径, $q_{n}: \tan (q)=-\alpha q$ を満たす一連の解 $q$ の $n$ 番目の正の解である.

Fig. 3 は気相系の測定装置（Fig. 1) で測定した吸 着量の経時変化を, Fig. 4 は液相系の測定装置 （Fig. 2）で測定したバルク相中の拡散物質の経時変 化の一例を示す。それぞれの経時変化は式（1）によ り良好に表せ, 結晶内拡散係数 $\left(D_{\mathrm{ad}}\right)$ が得られる. ここで, 添え字 $\operatorname{ad} は$ 吸着過程で測定した值を意味 する.

\section{3. ミクロ孔内における結晶内拡散係数}

ミクロ孔を有する固体触媒であるゼオライトの中 で代表的なものに MFI型ゼオライト（ZSM-5 や silicalite-1）が挙げられる. 結晶性の良い MFIは立方形, coffin 形の結晶を持つ. Coffin 形では厚み方向に straight channelの軸が配置される. サイズが $2 L の$ 結 晶を拡散分子が透過する際に, channel内の拡散距離 は, straight channelが透過軸に沿って存在する場合 には $2 L に$, zigzag channelが透過軸に沿って存在す る場合にはおよそ $1.4 \times 2 L$ になる。 また，拡散速度 は $D /$ (移動距離)2で表せるので straight channel内の 拡散速度は zigzag channelの（1.4） ${ }^{2}=1.96$ 倍になる. このことは結晶が立方形の場合も同様である。した がって, 拡散は straight channel 内が支配的となるた め，式（1）を用いる.

液相系の測定は，一例として MFI型ゼオライト細 孔径（0.55 nm）とほぼ同程度の分子径を有するベン ゼン分子を拡散分子に, 溶媒にシクロヘキサンを用 


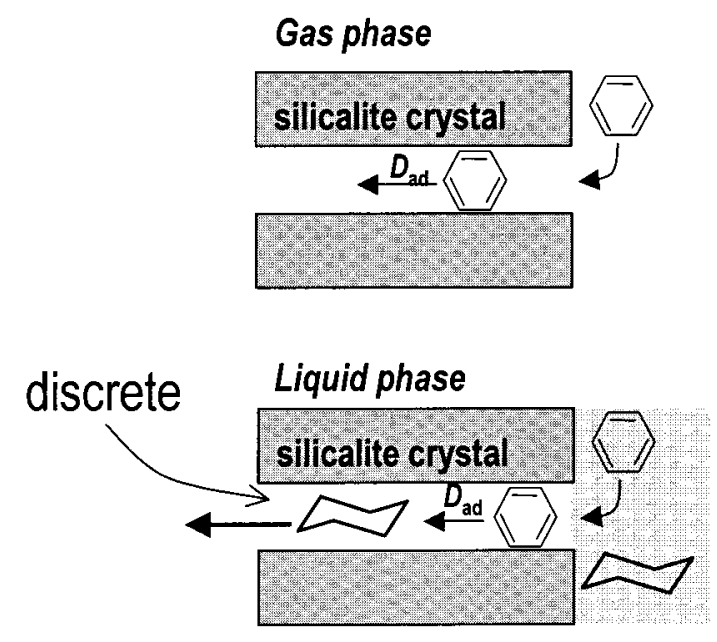

Fig. 6 Molecular diffusion image of benzene within silicalite-1.

いた. silicalite-1（酸点を有しないMFI型ゼオライト) を吸着剂に用いた時の結晶内拡散係数のArrhenius プ ロットを Fig. 5 に示す．比較の為に，気相系での結晶 内拡散係数も加えて示した。気相, 液相での silicalite-1 細孔内にお拮晶内拡散係数は一本の直線 で相関されている。これは，分子の大きさと細孔径 がほぼ同程度であるため, 分子と細孔壁との物理的 抵抗が優位な形状拡散領域特有の結果であると言え る．液相系では，ベンゼンーシクロヘキサン溶液か らベンゼンが silicalite-1 細孔内へ移動する際, バルク の連続相から分子が discreteされ，分子が連続相では 無く個々に分離した形で細孔内を移動すると予想さ れる (Fig. 6)。この為, 気相の場合と同じ機構で細 孔内を分子が移動していると考えられる。それゆえ， 形状拡散が支配的な silicalite-1の細孔内では, 結晶内 拡散係数はバルク相の状態に影響されないと言える. さらに，この結果からシクロへキサンの拡散速度は ベンゼンのものより速いということがわかる7 ${ }^{7}$. 吸着 等温線から得られる分配係数 $(H)$ と結晶内拡散係数 と分配係数を乗じて得られる有効拡散係数 $\left(D_{\text {eff }}=\right.$ $\left.H \times D_{\mathrm{ad}}\right)$ を Fig. 7 に示す． 溶媒の有無により分配係 数に 100 倍程度の違いが見られる為, 有効拡散係数に も 100 倍の違いが見られる。つまり，液相と気相で測 定される有効拡散係数の 100 倍近い值の差は，共存物 質 (溶媒) の有無による細孔内の拡散分子の存在量 に由来しており, 個々の拡散分子の移動度は相の違 いに依存せず同じであることが分かる.

\section{4. メソ，マクロ孔を有する固体触媒細孔内 液相拡散係数}

近年，MCM-41やFSM-16に代表されるメソ孔を有

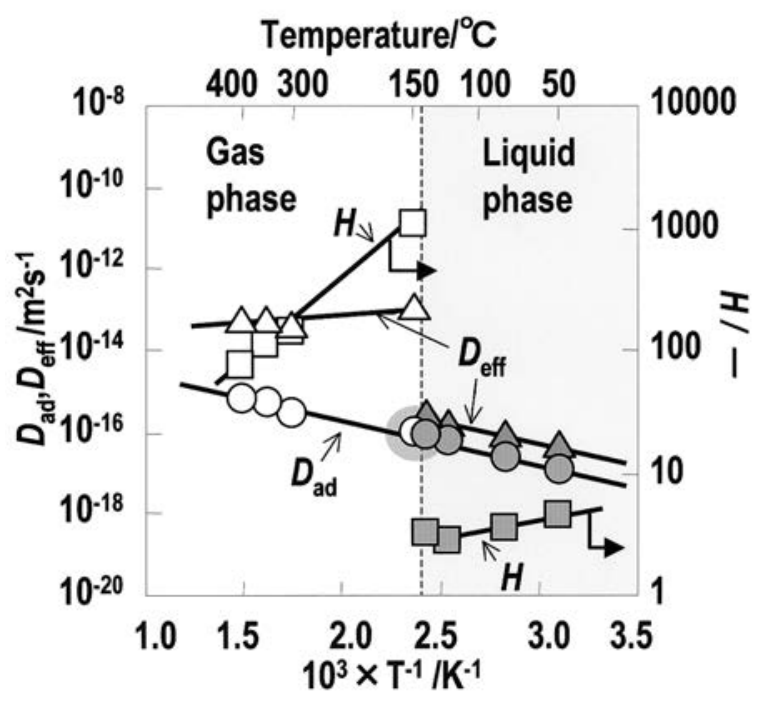

Fig. 7 Arrhenius plots of the intracrystalline diffusivity $\left(D_{\text {ad }}\right)$, effective diffusivity $\left(D_{\text {eff }}\right)$ and partition factor $(H)$ of benzene within silicalite-1 in the gas and liquid phases.

Table 2 Pore diameters of catalysts used in our work

\begin{tabular}{cc}
\hline catalyst & pore diameter $(\mathrm{nm})$ \\
\hline silicalite-1 & 0.6 \\
$\mathrm{~T}-\mathrm{C} 10$ & 2 \\
$\mathrm{~T}-\mathrm{C} 16$ & 2.7 \\
$\mathrm{~T}-\mathrm{C} 18$ & 3.1 \\
$\mathrm{~T} 172$ & 3.8 \\
$\mathrm{Silica}$ gel & 10 \\
$\gamma-\mathrm{Al}_{2} \mathrm{O}_{3}$ & 190 \\
$\mathrm{SiO}_{2}-\mathrm{Al}_{2} \mathrm{O}_{3}$ & 680 \\
\hline
\end{tabular}

する固体触媒の開発や，それらを用いた研究が盛ん に行われている。 そこで，メソ，マクロ領域を含め 一連の細孔径について検討する必要があると考えた. MCM-41（Mobil社によって 1992 年に開発された. MCM とは Mobil's Composition of Matterの 41番目に 合成に成功）や蜂の巣状の細孔形態を有する FSM-16 などのメソポーラスシリカ触媒は均一な一次元細孔 を有することが知られている. しかし，これらは silicalite-1のような規則的粒子形状を有しないため， 1 次粒子径を同定することが出来ない.

Yano $ら$ alkyl-trimethylammonium halide (ATMAX, $\mathrm{X}=\mathrm{Br}, \mathrm{Cl}$ ) をテンプレートに用い, 放 射状にメソ細孔が形成された球状粒子の合成方法の 開発に成功している ${ }^{24}$. 更に, 細孔径の制御にも成 

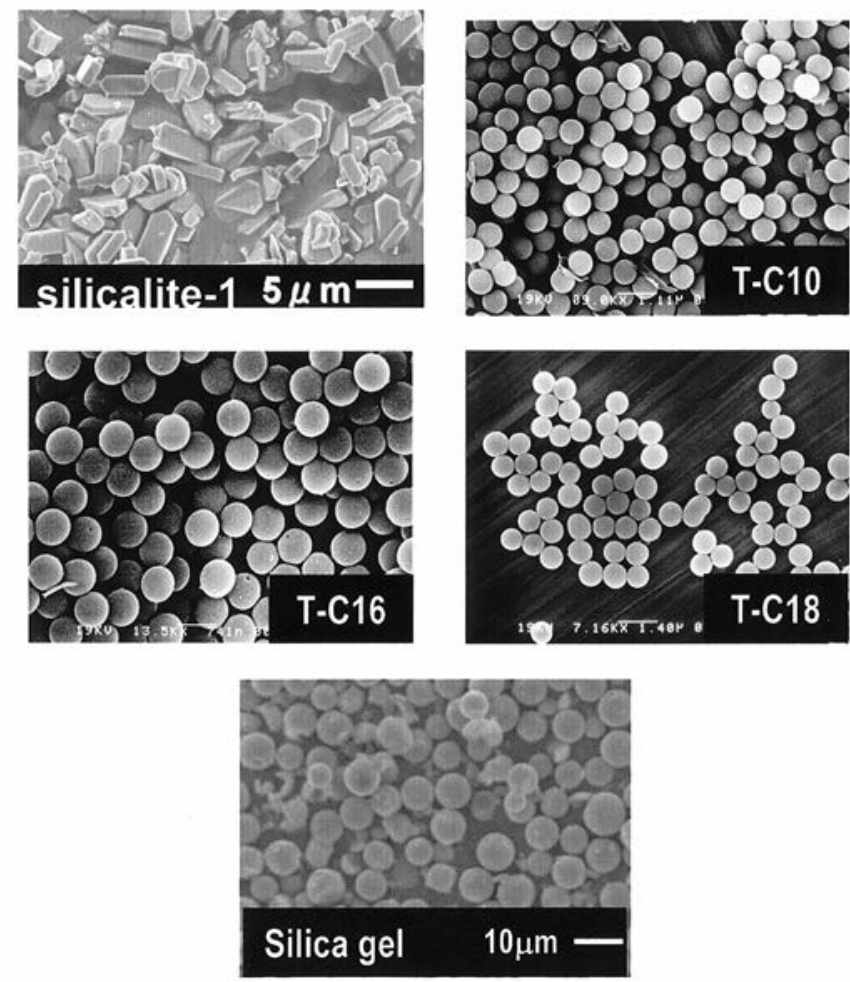

Fig. 8 SEM images of catalysts used in our work.

功している ${ }^{24)}$. そこで, Yano らのメソポーラス触媒 を用い細孔内液相拡散係数の測定を行ったので紹介 する。用いた固体触媒とその細孔径， SEM 像につい て Table 2 およびFig. 8 に，これら一連の固体触媒を 用いベンゼンーシクロヘキサン系において測定した 結晶内拡散係数の結果を Fig. 9 に示す. $2 \sim 4 \mathrm{~nm}$ 程 度の細孔を有する固体触媒では, 結晶内拡散係数は ミクロ孔を有する silicalite-1の拡散係数と比較して同 程度か, それより小さい值となっていることが分か る.これは，メソ細孔より細孔径が大きい領域にお いては, 細孔半径方向に分子が 2 分子以上入ることが 可能である為に，形状拡散で見られた拡散分子と細 孔壁の物理的抵抗による影響のみならず，拡散分子 と細孔壁に吸着した溶媒分子との化学的相互作用が 強く影響している為であると考えられる。また，マ ク口孔を有する固体触媒細孔内での拡散係数は, ミ クロ孔を有する silicalite-1 細孔内での拡散係数（この 場合，形状拡散）と比較して $10^{7}$ 程度大きい值となっ た.この值は, 液相中での分子拡散の推算式である Wilke-Chang式から導出された拡散係数に近い值であ る. 液相分子拡散推算式の Wilke-Chang 式は式 (3) で表される25).

$$
D=7.4 \times 10^{-12}\left(\beta M_{2}\right)^{0.5} T / \eta_{2} V_{\mathrm{m}, 1}^{0.6}
$$

ここで, $M_{2}$ は拡散媒の分子量, $\eta_{2}$ は粘度, $V_{\mathrm{m}, 1}$ は

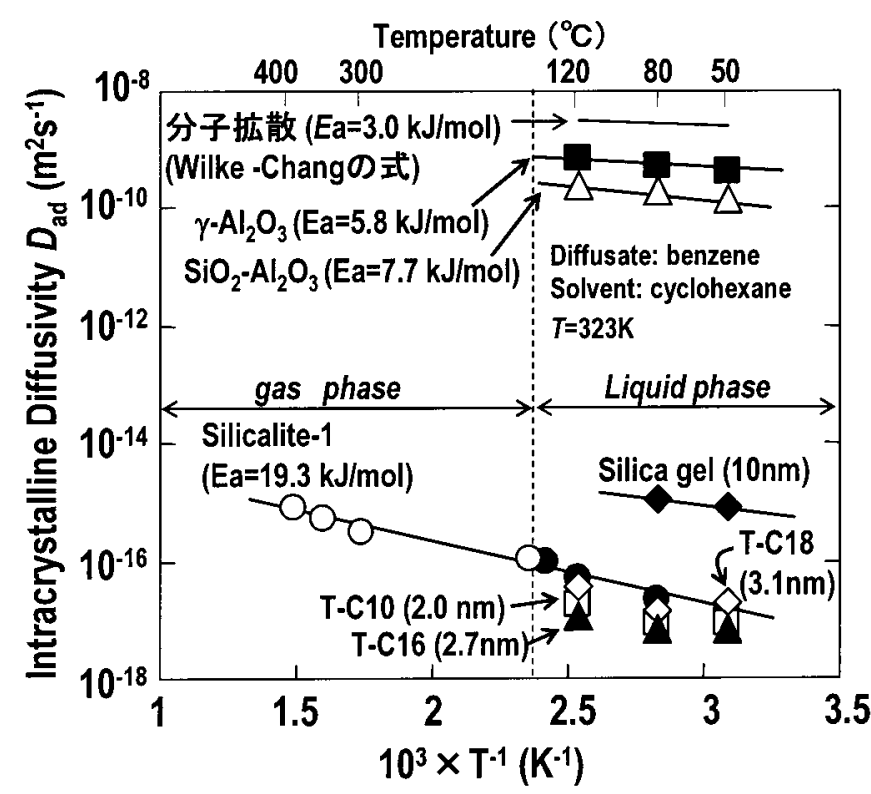

Fig. 9 Arrhenius plots of the intracrystalline diffusivity of benzene within meso porous and macro porous materials.

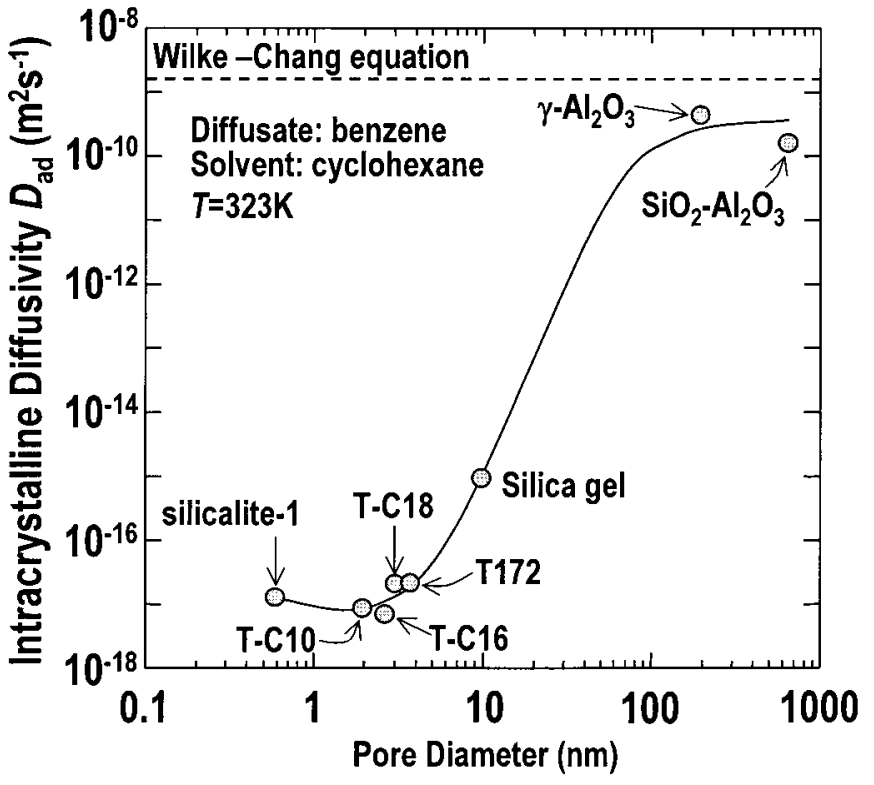

Fig. 10 The relation between pore diameter and $D_{\text {ad. }}$.

標準沸点における液相のモル体積, $\beta$ は拡散媒の会



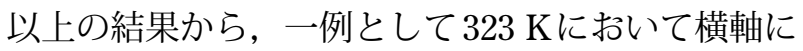
細孔径を縦軸に結晶内拡散係数としてプロットする と Fig. 10のグラフが得られる. 固体触媒細孔内の液 相拡散係数は大きく 3 つの領域に分けられる.1つ目 は, 細孔径が拡散分子径とほぼ等しく, バルクの連

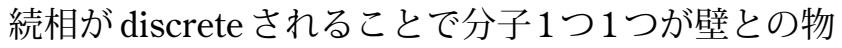
理的抵抗を受けながら移動する形状拡散領域. 2 つ目 は, 細孔内の拡散分子の移動が細孔壁との物理的抵 
抗のみならず細孔壁に吸着した溶媒分子との化学的 相互作用を強く受けながら移動する領域. そして $3 つ$ 目は，細孔壁の影響は無視小であり，分子間の相互 作用のみを強く受け移動する分子拡散領域である. また, Fig. 10を用いることで任意の細孔径を有する 固体触媒細孔内での拡散係数の予測が可能である. この Figを用いた応用例として, FSM-16の平均拡散 距離の推測について紹介する. FSM-16は先ほども記 載したように，均一な一次元細孔を有している。し かし，規則的な粒子形状を有しておらず，SEMから もアモルファスシリカの塊のように観察されるのみ である. 我々は細孔径 $3.2 \mathrm{~nm}$ の FSM-16を用い，平 均拡散距離の推測を行った. Fig. 10から細孔径が 3.2 $\mathrm{nm}$ の時, 結晶内拡散係数は $1.5 \times 10^{-17} \mathrm{~m}^{2} \mathrm{~s}^{-1}$ と読み 取ることが出来る．このFSM-16を用い，液相系での ベンゼン分子の吸着による経時変化は式 (1) 中の $D_{\mathrm{ad}} / L^{2}$ の值が $3.45 \times 10^{-4} \mathrm{~s}^{-1}$ の時良好に表すことがで きる. この值に拡散係数を代入することで平均拡散 距離が求まり, $2 L=400 \mathrm{~nm}$ となる. 一方, Sasaki ら は，FSM-16細孔のナノ空間を利用し白金ナノワイヤ 一の合成に成功している ${ }^{26)}$. 用いる試料は異なるた め直接比較は難しいが, Sasaki らが得たナノワイヤ 一の長さが 50 ～ $250 \mathrm{~nm}$ であることから，推算值はほ ぼ妥当な值ではないかと考えられる。ここでは示し ていないが, 結晶内拡散係数から任意吸着量に到達 するまでの時間を推測可能であるなど, 拡散係数か ら得られる情報は様々であり, 触媒設計の上で極め て重要であることがわかる.

\section{5. おわりに}

本稿では, 細孔内液相拡散係数の測定法から一連 の細孔径を有する固体触媒細孔内での拡散係数につ いて最近の研究から紹介した。単に装置設計で用い る有効拡散係数ではなく, 分配係数と結晶内拡散係 数を分離して解析することで細孔内の分子の挙動が 把握できる. 気相系とは異なり, 液相系では測定対 象が濃度となり測定が困難になるが，ここで紹介し たラマン分光法を利用した測定方法を用いることで, 高温領域での拡散係数をin-situで測定することが可 能となった.さらに，ラマン分光法は水を含んだ系 にも対応可能であるという特性から，ゼオライト膜 を用いて液相系混合物の分離について検討されてい るような系に対しても適応できるのではないかと期 待される.

これまで, 一例としてベンゼンーシクロヘキサン 系について検討してきた. 本稿で示したように，分 子サイズと比較して, ある程度細孔径の大きい領域
では拡散物質と共存する溶媒との相互作用が強く影 響を及ぼす。この為, 溶媒分子サイズや分子間の化 学的作用を考慮に入れ液相系の拡散現象を追求して いきたいと考えている.

\section{文献}

1) Tago $T$, Iwakai $K$, Morita $K$, Tanaka $K$, Masuda $T$ : Catalysis Today, 105, 662-666 (2005)

2) Masuda T, Otani S, Tsuji T, Kitamura M, Mukai SR : Sep. and Purif. Technol., 32, 181-189 (2003)

3) Hasegawa $Y$, Ikeda T, Nagase T, Kiyozumi $Y$, Hanaoka T, Mizukami F: J. Membr. Sci., 280, 397-405 (2006)

4) Zikanova A, Bulow M, Schlodder H : Zeolites, 7, 115-118 (1987)

5) Shen DM, Rees LVC : Zeolites, 11, 666-671 (1991)

6) Masuda T, Fukada K, Fujikata Y, Ikeda H, Hashimoto K : Chem. Eng. Sci., 51, 1879-1888 (1996)

7) Masuda T, Fujikata Y, Nishida T, Hashimoto K : Microporous and Mesoporous Materials, 23, 157-167 (1998)

8) Masuda T, Fukada K, Fujikata Y, Ikeda H, Hashimoto K : Microporous and Mesoporous Materials, 38, 323-332 (2000)

9) Choudhary VR, Akolekar DB, Singh AP : Chem. Eng. Sci., 44, 1047-1060 (1989)

10) Choudhary VR, Nayak VS, Mamman AS : Ind. \& Eng. Chem. Res., 31, 624-628 (1992)

11) Takahashi R, Sato S, Sodesawa T, Kamomae Y : Phys. Chem. Chem. Phys., 2, 1199-1204 (2000)

12) Takahashi R, Sato S, Sodesawa T, Nishida H : Phys. Chem. Chem. Phys., 4, 3800-3805 (2002)

13) Masuda T, Okubo Y, Mukai SR, Kawase M, Hashimoto K, Shichi A, Satsuma A, Hattori T, Kiyozumi Y : Chem. Eng. Sci., 56, 889-896 (2001)

14) Jobic H, Bee M, Caro J, Bulow M, Karger J : J. Chem. Soc., Faraday Trans., 56, 4201-4209 (1989)

15) Xial JR, Wei J : Chem. Eng. Sci., 47, 1123-1141 (1992)

16) Shah DB, Guo CJ, Hayhurst DT : J. Chem. Soc., Faraday Trans., 91, 1143-1146 (1995)

17) Song LJ, Rees LVC : Microporous and Mesoporous Materials, 6, 363-374 (1996)

18) Ruthven DM, Eic M, Richard E : Zeolites, 11, 647-653 (1991)

19) Jama MA, Delmas MPF, Ruthven DM : Zeolites, 18, 200204 (1997)

20) Sun MS, Talu O, Shah DB : AIChE J., 42, 3001-3007 (1996)

21) Garcia SF, Weisz PB : J. Catal., 144, 109-117 (1993)

22) Hashimoto K: "Hannnou-kogaku," Baifukan (1993)

23) Crank J : The Mathematics of Diffusion, Clarendon Press, Oxford (1975)

24) Yano K, Fukushima Y : J. Mater. Chem., 14, 1579-1584 (2004) 
25) Wilke CR, Chang P : AIChE J., 1, 264-270 (1955)

26) Sasaki M, Osada M, Sugimoto N, Inagaki S, Fukushima Y, Fukuoka A, Ichikawa M : Microporous and Mesoporous Materials, 21, 597-606 (1998)

(Received 13 September 2007;

Accepted 19 September 2007)

\section{著者略歴}

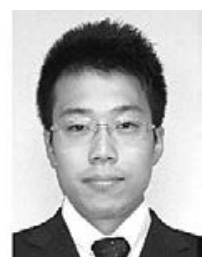

中坂 佑太（なかさか ゆうた）

2007 年 3 月 北海道大学大学院工学 研究科有機プロセス工 学専攻修士課程修了

同 年 4 月 北海道大学大学院工学 研究科有機プロセス工 学専攻博士課程進学 現在に至る

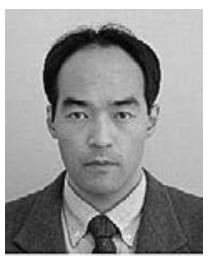

多湖 輝興（たご てるおき）

1998年 3月 京都大学大学院工学研 究科化学工学専攻博士 後期課程修了

同 年 4 月 九州大学大学院工学研 究科 助手

2002 年 4 月 北海道大学大学院工学 研究科 助手

2006 年 10 月 北海道大学大学院工学 研究科 助教授

2007 年 4 月 北海道大学大学院工学 研究科 准教授 現在に至る

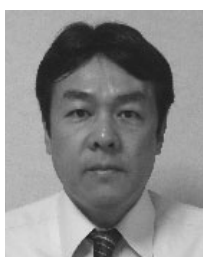

矢野 一久（やの かずひさ）

1983 年 3月 東京工業大学大学院理 工学研究科化学工学専 攻修士課程 修了

1989年 1月 豊田中央研究所入社

2004年 9 月 名古屋大学大学院博士 号取得

現在に至る

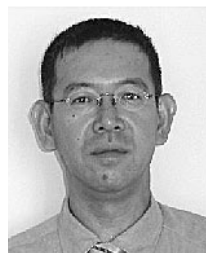

増田 隆夫（ますだ たかお）

1982 年 10 月 京都大学大学院工学研 究科化学工学専攻博士 後期課程 中退

同 年 同月 京都大学工学部助手 1989年 4月 京都大学工学部講師 1994年 2 月 京都大学工学部助教授 2001 年 4 月 北海道大学大学院工学 研究科教授 現在に至る 